\title{
Community Involvement in Tourism Development: A Case Study of Lenggong Valley World Heritage Site
}

\author{
Nur Zafirah A. Khadar ${ }^{1}$, Mastura Jaafar ${ }^{2}$, Diana Mohamad ${ }^{3}$ \\ ${ }^{1,3}$ Sustainable Tourism Research Cluster (STRC), Universiti Sains Malaysia, 11800 Penang, Malaysia \\ ${ }^{2}$ School of Housing, Building and Planning, Universiti Sains Malaysia, 11800 Penang, Malaysia
}

\begin{abstract}
This paper examines the empirical relationship between the economic impact and community involvement in the Lenggong Valley. Recommendations for improvement in development effectiveness through the development of a community centre for economic and social activities, with specific attention given to types of activity and community involvement stimulating the economic development in the Lenggong Valley. Heritage tourism development is a tourism in which arts, culture and heritage form a key attraction for visitors and it can be represented as an area of significant economic benefit to heritage sites. The tourism industry in Hulu Perak became more widespread after Lenggong Valley is recognized as a World Heritage Site. There is shown a positive effect on the development and economic prosperity.
\end{abstract}

\section{Introduction}

In general, the heritage tourism offers a range of cultural heritage products, from visiting monuments to discovering unique lifestyles, as a that could serve in cultural and heritage tourism demand [1]. UNESCO defines heritage tourism as "to create a discerning type of tourism that takes account of other people's cultures" [2]. Culture and heritage tourism are internationally recognized for its financial potential in addition to contributing to sustainable tourism development. More importantly, the heritage tourism paradigm shift and transformation may serve as the local communities' economical gains platform. Indeed, culture and heritage tourism has been gaining importance recently not only for its' economic gains but due to more sustainable approaches.

As rural and regional economies go through difficult times of change, it may seem to some local communities that heritage can help in terms of economic gains. When what is old and valued in the community can no longer serve its original function, surely it can still attract funding and tourism as a part of cultural heritage. It is a well known fact that a natural link exists between cultural heritage tourism and regional development. Regional development is a key factor which contributes to the economic welfare of the host country.

In this study, we are focusing on Lenggong Valley that situated in the northern part of Perak, Malaysia, located 100 miles from the north of Ipoh; which is famous for heritage, culture and archaeological attraction [3]. UNESCO has gazetted Lenggong Valley Archaeological Heritage as one of the UNESCO World Heritage Site on $30^{\text {th }}$ June 2012. The Lenggong Valley is one of Peninsular Malaysia's most important areas of archaeology, as excavations have revealed many traces of Malaysia's prehistoric. 
Of interest, it is known for the evidence of ancient human activity on the Peninsula. The Lenggong Valley landscape has gone a very limited changes were to date, it remains surrounded by green vegetation and limestone hills. Apart from an open-air museum, the Lenggong Valley house legends, skeletons, cave drawings and precious finds such as jewellery, pottery weapons, and stone tools.

These attributes are envisaged as pull factors for business activities and thus, have an economic impact on and investment in Lenggong Valley. Traditionally, local communities in Lenggong valley are involved in the primary economic sectors, which are agriculture and fisheries [4]. Therefore, the study aims to examine and discuss the Lenggong Valley toward community involvement through economic impact in heritage tourism development activities.

\section{Literature review}

\subsection{Economic impact from heritage tourism development}

Heritage tourism encompasses elements of living culture, history, and natural history of a place that was intended to preserve and maintained for the future generation. More specifically, it focused upon experiencing cultural environments, including landscapes, the visual and the performing arts and special lifestyles, values, traditions, and events. Other than influencing the economic development, these elements contribute to present-future growth stability.

Heritage and culture play a crucial role in encouraging an excellent team play of resources management (cultural and natural) between community residents, organizations, civic institutions and governments; especially in rural settings. More importantly, these unique elements characterize the community and through this characterization, it draws community and visitors alike [5]. This facilities harmony and understanding among people, it supports culture and helps renew tourism [6]. Therefore, heritage tourism sustainable management seeks to achieve a balance between the preservation of heritage resources and providing economic development opportunities for the community.

Heritage tourism is one kind of prevalent special interest tourism (SIT) and usually related to the domains of cultural tourism and urban tourism [7]. Heritage tourism successfulness is calculated in the course of attractive heritage resources management and implementation of effective policy; by which, could establish through residents' tourism development supportiveness [8] have taken the local residents' attitude into account when examining the relationships between the locals' involvement towards development in heritage sites. Community participation in planning and development stages is also a fundamental necessity for sustainability of development [9], which in turn, is essential for finding a balance between economic prosperity, environmental protection and social equity and business opportunity [10].

Heritage tourism sustainable management seeks to achieve a balance between the preservation of heritage resources and providing economic development opportunities for the community. For the success of heritage tourism and its sustainability, it is important to understand community involvement impacts on the heritage tourism development. Pragmatic heritage tourism development benefits the community in terms of appreciation for and pride in their local city and its history.

The influence of a well-planned and well-managed local tourism programs extends to improving the local community economy and enhancing the quality of life. The benefits may include the potential for profitable domestic industries - hotels, restaurants, transportation systems, souvenirs and handicrafts and guide services. 


\section{Research Methodology}

A self-administered survey was taken in June 2014 as the data collection instrument by this study. Targeting the local community that resides in 15 villages of the Lenggong Valley, this study has successfully retrieved 85 per cent usable questionnaires. Using a four-point Likert scale $(1=$ strongly disagree, $4=$ strongly agree), respondents were asked to rank their answers on 221 questions related to tourism development in the Lenggong Valley. The questions were based on a review of the literature questionnaire consisted of six parts; however, for the purpose of this study, only Part 1 and Part 6 were used that containts Part 1 - addresses the respondents' demographic information with 9 items gender, age, race, experience in work, indigenous people, occupation, personal monthly income, education level and job profession of the community and Part 6 - perceptions of local community in social and economic impacts) [11].

\section{Data analysis}

The survey data was analysed in SPSS version 22 by using the summary of descriptive statistics of respondents' profile and paired sample t- test between respondents' profile and economic impacts of community involvement in Lenggong Valley. Descriptive statistics are used to describe the basic features of the data in a study. A paired sample t-test is used to determine whether there is a significant difference between the average values of the same measurement made under two different conditions. Both measurements are done on each unit in a sample, and the test is based on the paired differences between these two values. The usual null hypothesis is that the difference in the mean values is zero. The null hypothesis is:

$\mathrm{H}_{\mathrm{o}}$ : There is a significant difference between a respondents' profile and economic impacts

$\mathrm{H}_{1}$ : There is no significant difference between a respondents' profile and economic impacts

\subsection{Characteristics of respondents}

Of 221 total respondents', 55.2 percent were female respondents and 44.8 percent were male respondents (Table 1). The respondent population is aged between 17 years old to 80 years old, with majority of respondents' fall into $17-26$ years old category ( 29 per cent). This followed by 53 to 62 years old (17.6 percent), 44 to 53 years old (17.2 percent). 26 to 35 years old (14.9 percent), 35 to 44 years old (14.5 percent), 62 to 71 years old (5.9 percent) and only 0.9 percent were aged between 71 to 80 years old. 43 percent respondents' were in others job profession followed by 21.3 percent in support of government and private sectors, 17.6 percent in an agriculture, 10 percent in food industries, 3.2 percent in handicraft field, 2.7 percent in transportation and another 2.3 percent in accommodation filed.

Moreover, 56.1 percent of the respondents' are Secondary School in Malaysian Certificate of Education (SPM) holder, 16. 7 percent possess a Secondary School in Lower Secondary Assessment (PMR), Primary School and College that have 9 percent, 5.4 percent with a Bachelor and 3.6 graduated from high school. This study found 33.5 percent respondents' with no monthly income and 29.9 percent with monthly income below RM 1,000. This is followed by 27.1 percent with monthly income between RM 1,000- RM 2,000 of income, 6.8 percent earned between RM 2,001- RM 3,000 monthly, 2.3 percent with monthly income between RM 3,001- RM 4,000 and 0.5 percent enjoy RM 4,001 - RM 5,000 of income. 
Table 1. Respondents' Profile

\begin{tabular}{|c|c|c|}
\hline \multicolumn{3}{|c|}{ Sample data $(n=221)$} \\
\hline Variables & Frequency & $(\%)$ \\
\hline \multicolumn{3}{|c|}{ Gender } \\
\hline Male & 122 & 55.2 \\
\hline Female & 99 & 44.8 \\
\hline \multicolumn{3}{|c|}{ Age } \\
\hline $17-26$ & 64 & 29.0 \\
\hline $26-35$ & 33 & 14.9 \\
\hline $35-44$ & 32 & 14.5 \\
\hline $44-53$ & 38 & 17.2 \\
\hline $53-62$ & 39 & 17.6 \\
\hline $62-71$ & 13 & 5.9 \\
\hline $71-80$ & 2 & 0.9 \\
\hline \multicolumn{3}{|c|}{ Job Profession } \\
\hline Transportation & 6 & 2.7 \\
\hline Accomodation & 5 & 2.3 \\
\hline Food & 22 & 10.0 \\
\hline Handcraft & 7 & 3.2 \\
\hline Agriculture & 39 & 17.6 \\
\hline Support & 47 & 21.3 \\
\hline Others & 95 & 43.0 \\
\hline \multicolumn{3}{|c|}{ Education Level } \\
\hline Primary School & 20 & 9.0 \\
\hline Secondary School (PMR) & 37 & 16.7 \\
\hline Secondary School (SPM) & 124 & 56.1 \\
\hline High School & 8 & 3.6 \\
\hline College & 20 & 9.0 \\
\hline Bachelor & 12 & 5.4 \\
\hline \multicolumn{3}{|c|}{ Income } \\
\hline Below RM $1,000.00$ & 66 & 29.9 \\
\hline RM $1,000.00$ - RM 2,000.00 & 60 & 27.1 \\
\hline RM 2,001.00 - RM 3,000.00 & 15 & 6.8 \\
\hline RM 3,001.00 - RM 4,000.00 & 5 & 2.3 \\
\hline RM 4,001.00 - RM 5,000.00 & 1 & 0.5 \\
\hline Without income & 74 & 33.5 \\
\hline
\end{tabular}

\subsection{Paired sample T-Test between economic impacts and respondent characteristics}

In this study, paired sample t-test was used to determine the relationship between economic impacts and characteristics of the respondents' that involved in heritage tourism development at Lenggong Valley, Perak. The dependent variables that have chosen were contributed to the National Income (GDP) [A], authorities often hold meetings with the local community to discuss the development of tourism in Lenggong [B], authorities are also encouraging local community involvement in tourism 
activities [C] and prices of goods and services increasing [D]. The independent variables include income $[\mathrm{AI}]$, job profession $[\mathrm{AII}]$, age $[\mathrm{BI}]$, gender $[\mathrm{CI}]$ and education level [CIII].

From Table 2 the first row observes the relationship between contribute to the National Income (GDP) $[\mathrm{A}]$ and income $[\mathrm{AI}]$ and job profession [AII]. It shows the [AI] $\mathrm{t}$ - statistics, $\mathrm{t}=7.241$, and $\mathrm{p}=$ 0.000 and for the $[\mathrm{AII}]$ shows the $\mathrm{t}$-statistics, $\mathrm{t}=-11.961$, and $\mathrm{p}=0.000$ i.e., a very small probability of this result occurring by chance, under the null hypothesis of no difference. Therefore, the null hypothesis is rejected for [AI] and [AII]. On the other hand, second row observation shows the relationship between authorities often hold meetings with the local community to discuss the development of tourism in Lenggong [B] and age [BI] and job profession [BII]. The results obtained $[\mathrm{BI}]$ where $\mathrm{t}$ - statistics, $\mathrm{t}=4.376$, and $\mathrm{p}=0.000$ and for the $[\mathrm{BII}]$ indicates $\mathrm{t}$-statistics, $\mathrm{t}=-15.519$, and $\mathrm{p}=0.000$. The null hypothesis is rejected for [BI] and [BII] given the significant relationship between the variables. Meanwhile, for the third row implies a relationship between authorities are also encouraging local community involvement in tourism activities [C] and gender [CI], age [CII], education level [CIII] and job profession [CIV] hence the results explained in the table for the [CI] tstatistics, $\mathrm{t}=35.217$, and $\mathrm{p}=0.000$, for the $[\mathrm{CII}]$ indicator, $\mathrm{t}$ - statistics, $\mathrm{t}=6.188$, and $\mathrm{p}=0.000$ followed by [CIII] indicator $\mathrm{t}$-statistics, $\mathrm{t}=6.996$, and $\mathrm{p}=0.000$ and [CIV] indicator $\mathrm{t}$-statistics, $\mathrm{t}=$ 14.405 , and $p=0.000$. Next, for the last row describe the relationship between the price of goods and services increasing [D] and income [DI] subsequently the result obtained [DI] as t-statistics, $t=4.000$, and the $\mathrm{p}=0.000$.

Table 2. Paired sample T-test between variables

\begin{tabular}{|c|c|c|c|c|c|}
\hline \multicolumn{6}{|c|}{ Paired Samples Test } \\
\hline $\begin{array}{c}\text { DV } \\
\text { (Economic Indicators) }\end{array}$ & $\begin{array}{c}\text { IV } \\
\text { (Respondents } \\
\text { Profile Indicators) }\end{array}$ & Mean & $\begin{array}{c}\text { Std. } \\
\text { Deviations }\end{array}$ & $\mathbf{t}$ & $\begin{array}{l}\text { Sig. } 2 \\
\text { tailed }\end{array}$ \\
\hline $\begin{array}{l}\text { Contribute to the National } \\
\text { Income (GDP) [A] }\end{array}$ & $\begin{array}{l}\text { Income }[\mathrm{AI}] \\
\text { Job Profession }[\mathrm{AII}]\end{array}$ & $\begin{array}{r}1.081 \\
-1.416\end{array}$ & $\begin{array}{l}2.220 \\
1.760\end{array}$ & $\begin{array}{r}7.241 \\
-11.961 \\
\end{array}$ & $\begin{array}{l}0.000^{* *} \\
0.000^{* *}\end{array}$ \\
\hline $\begin{array}{l}\text { Authorities often hold } \\
\text { meetings with the local } \\
\text { community to discuss the } \\
\text { development of tourism in } \\
\text { Lenggong [B] }\end{array}$ & $\begin{array}{l}\text { Age }[\mathrm{BI}] \\
\text { Job Profession [BII] }\end{array}$ & $\begin{array}{r}0.566 \\
-2.090\end{array}$ & $\begin{array}{l}1.922 \\
2.002\end{array}$ & $\begin{array}{r}4.376 \\
-15.519\end{array}$ & $\begin{array}{l}0.000^{* *} \\
0.000^{* *}\end{array}$ \\
\hline $\begin{array}{l}\text { Authorities are also } \\
\text { encouraging local } \\
\text { community involvement in } \\
\text { tourism activities [C] }\end{array}$ & $\begin{array}{l}\text { Gender }[\mathrm{CI}] \\
\text { Age }[\mathrm{CII}] \\
\text { Education Level [CIII] } \\
\text { Job Profession [CIV] }\end{array}$ & $\begin{array}{r}2.330 \\
0.769 \\
0.747 \\
-1.887\end{array}$ & $\begin{array}{l}0.984 \\
1.848 \\
1.587 \\
1.947\end{array}$ & $\begin{array}{r}35.217 \\
6.188 \\
6.996 \\
-14.405\end{array}$ & $\begin{array}{l}0.000^{* *} \\
0.000^{* *} \\
0.000^{* *} \\
0.000^{* *}\end{array}$ \\
\hline $\begin{array}{l}\text { Prices of goods and services } \\
\text { increasing [D] }\end{array}$ & Income [DI] & 0.633 & 2.354 & 4.000 & $0.000^{* *}$ \\
\hline
\end{tabular}

** Significant at the 0.05 level (2-tailed) 


\section{Discussion and conclusion}

This study has investigated the community involvement that supports the economic impact by considering economic dependence, community attachment, the local authority's role and perceived tourism impacts to support heritage tourism development. According to the findings, it is learned that respondents' characteristics play significant role in improving the community involvement in Lenggong Valley. The heritage tourism will help to increase the local development in making the Lenggong Valley as an attractive historical site in Malaysia. The coming of foreign and local tourist would indirectly generate economic growth in the district of Lenggong Valley, hence can increase the revenue authorities and the income of the population. Most of the respondents agreed on the importance role of local authority and perceived by having a better plan, it would help the province to increase its tourism economically as well.

The improvement of agriculture and support fields could contribute to increase in Contribute National Income (GDP). This paper suggests the improvement in the form of training program to equip the respondents with skills, and hence can encourage supports towards community participation in heritage tourism development. Government may continue giving assistance by way of financial support in the development of tourism infrastructure. Besides that, the government may offer financial assistance for small entrepreneurs to produce products that can encourage local and international tourists to come and visit the Lenggong Valley, in fact, directly can increase economic impacts in tourism development [13]. Moreover, despite the negative significant results between job profession and GDP, it is within this paper interest to emphasize on job profession goods production relationship in terms of resources management as documented by [6].

On the other hand, potential to encourage participation in heritage tourism development as an entrepreneur, further result shows that the male respondents were more responsive especially those who are occupied in agriculture and support fields. This suggests the crucial role in implementing psychological perspective into heritage tourism development plan. In the context of encouragement for community participations results did not highlight a role played by education level. Therefore, complicated approach was deemed unnecessary in developing the promotional framework. Higher level of community attachment could be translated an effective resources investment and management, by which, directly influencing the tourism development support. In cases of incomeprices of goods and services relationship, it was learned that increase in prices of goods and services could be accepted provided that the respondents' have substantial in monthly income.

\section{Acknowledgement}

This project was funded through a research grant from the Ministry of Higher Education, Malaysia under the Long-Term Research Cluster Grant Scheme 2011 [STRC Grant No. 1001/PTS/8660012].

\section{References}

1. K. Caton \& C.A. Santos, Heritage Tourism On Route 66: Deconstructing Nostalgia, Journal of Travel Research, 45, 4, 371-386 (2007)

2. UNESCO, (2005), "Cultural Tourism”, http://portal.unesco.org/culture/en/ev.phpurl_id=11408\&url_do=do_printpage\&url_section=201.html, Retrieved 01 March 2008.

3. M. Saidin, Bukti Prasejarah Di Malaysia. Dewan Bahasa dan Pustaka, Kuala Lumpur, Malaysia (2010)

4. M. Jaafar, A.A.A. Rashid, S.A. Maideen \& S.Z. Mohamad, Entrepreneurship In The Tourism Industry: Issues in Developing Countries. International Journal of Hospitality Management, 30, 827-835 (2011) http://dx.doi.org/10.1016/j.ijhm.2011.01.003

5. $\quad$ Silberberg, Ted. "Cultural Tourism and Business Opportunities for Museums and Heritage Sites.” Tourism Management 16, 5, 361-365 (1995)

6. G. Richards, Production and consumption of European Cultural Tourism. Annals of Tourism Research: Tillburg University Press (1996) 


\section{ICTR}

7. C.F. Chen \& F.S. Chen, Experience Quality, Perceived Value, Satisfaction And Behavioral Intentions for Heritage Tourist, Tourism Management, 31, 29-35 (2009)

8. N. Uriely, A.A. Israeli \& A. Reichel, Heritage Proximity and Resident Attitudes Toward Tourism Development, Annals of Tourism Research, 29, 3, 859-862 (2002)

9. P. Dyer, D. Gursoy, B. Sharma \& J. Carter, Structural Modeling Of Resident Perceptions Of Tourism And Associated Development on The Sunshine Coast, Australia :Tourism Management, 28, 409-422 (2007)

10. R. Isaksson \& R. Garvare, Measuring sustainable development using process models, Managerial Auditing Journal, 18, 8, 649-656 (2003)

11. D.W. Ko \& W.P. Stewart, A Structural Equation Model Of Residents' Attitudes For Tourism Development, Tourism Management, 23, 521-530 (2002)

12. A. Mathieson \& G. Wall, Tourism: Economics, Physical and Social impacts. London: Longman (1982)

13. K.L. Andereck, K.M. Valentine, R.C. Knopf \& C.A. Vogt, Residents' Perceptions of Community Tourism Impact, Annals of Tourism Research, 32, 4, 1056-1076 (2005)

14. D. Gursoy, C. Jurowski \& M. Uysal, Resident Attitudes: A Structural Modeling Approach, Annals of Tourism Research, 29, 1, 79-105 (2002)

15. D. Gursoy \& D.G. Rutherford, Host Attitudes Toward Tourism: An Improved Structural Model, Annals of Tourism ResearchI, 31, 3, 495-516 (2004 